\title{
ADDENDUM TO THE ABSTRACTS FOR THE PAN-AMERICAN REGIONAL WOOD ANATOMY CONFERENCE
}

Curitiba, Paraná, Brazil, January 20-26, 1985

(continued from IAWA Bulletin n.s. 5: 345-347)

G.B.L. COCCOLINI, Dipartimento di Biologia Vegetale, Università 'La Sapienza', p. le A.Moro, 5, 00185 Rome, Italy. - Bronze Age wooden objects from the Ledro pile dwellings (Trento, Northern Italy).

During the excavations at the Ledro pile dwellings many well preserved wooden artefacts such as sickles, hafts, clubs, bows, combs, ladles, spatulas and a large number of containers have been recovered. The histological study of various hundreds of these objects showed that different kinds of wood were employed for objects that had a different use: Yew wood (Juniperus) for sickles and spatulas; Cornelian cherry (Cornus) for clubs; Oak (Quercus) for boards, and so on. The relation between the form in nature and the use the artefact was intended for will be pointed out: sickles have been obtained from branches forking at wide angles; similarly, hafts have been made from the angular part of a branch delimited by a main axis and by a secondary one.

Comparative examination of type of artefact, type of wood, origin of the artefact, cutting planes of the wood, etc. has proved to be useful for a better understanding of wood technology in Northern Italy during the Bronze Age.

SUSANA A. COZZO, Coronal Díaz 1718-7 piso, 1425 Capital Federal, Argentina. - The secondary xylem of trees and shrubs of Compositae growing in Argentina.

The wood anatomy of trees and shrubs from Argentina belonging to the Compositae was studied. The wood structure will be reported of 17 species belonging to the following genera: Baccharis, Cnicothamnus, Dasyphyllum, Dinoseris, Eupatorium, Gochnatia, Tessaria and Vernonia. These genera belong to 5 of the 13 known tribes in the family. This study constitutes a significant increase in our knowledge of the wood anatomy of Compositae.

RICARDO VILLALBA, Laboratorio de Dendrocronologia, Instituto Argentino de Nivologia y Glaciologia, Casilla de Correo 330, 5500 Mendoza, Argentina. - Xylem structure and cambial activity in Prosopis flexuosa DC.

A description of the wood structure of Prosopis flexuosa is given. It was found that it is semi-ring-porous, shows pores solitary, in multitiples and in cluster arrangement and small to large-sized vessels with simple perforation plates. Vessel walls are thick. Rays are multiseriate and homogeneous. Axial parenchyma is paratracheal and the fibres conform to the libriform type. The conducting tissue is highly adapted to very low rainfall and prolonged dry periods.

Seasonal variations in cambial activity have been investigated from July 1982 to June 1984 . $P$. flexuosa trees seem to be well adapted to their environment, having an annual rhythm of wood production which coincides with the climatic rhythm. Cambial activity is initiated in the last week of October, reaches a peak in November, December and ceases in April. The initiation of cambium activity seems to be endogenous. A dormant period is noticed when defoliation takes place during the dry months. Although the growth rings are not always clearly demarcated, one growth ring is generally formed each year in the trunks of the trees studied.

BEN J. H. TER WELLE, Institute of Systematic Botany, University of Utrecht, Heidelberglaan 2, P.O. Box $80.102,3508$ TC Utrecht, The Netherlands. - Differences in wood anatomy of lianas and trees.

Lianas are well represented in tropical forests, and also occur in temperate vegetations all over the world. Taxa with a climbing habit are found in c. 50 families. The wood anatomical pattern of climbing versus arborescent species in the same genus or family shows interesting trends. The percentage of surface area occupied by vessels, as seen in the transverse section, is much higher in climbing species than in non-climbing species. This is due either to an increase in the number of vessels per sq. $\mathrm{mm}$ and/or to an increase in the vessel diameter. Ray height and ray width are also larger in climbing species. These trends are found in climbers from tropical as well as temperate areas.

The typical ecological adaptation trends for temperate tree species, like the development of spiral thickenings on the vessel walls and the ring-porous distribution of the vessels, are also found in lianas. Since tropical lianas may support as much leaf biomass as big trees, and their stems are narrower, the efficiency of the xylem for water transport of lianas is much higher. The relatively high percentage of vessel tissue is most certainly one of the important factors in this respect. 